Alovsat G. Aliyev ${ }^{1}$, Roza O. Shahverdiyeva ${ }^{2}$

${ }^{1,2}$ Institute of Information Technology, ANAS, Baku, Azerbaijan

DOI: $10.25045 /$ jpis.v06.i2.07

1alovsat_qaraca@mail.ru, ${ }^{2}$ roza02@ rambler.ru

\title{
THE ANALYSIS OF INTERNATIONAL PRACTICE ON THE ESTABLISHMENT, ORGANISATION AND MANAGEMENT OF INNOVATIVE TECHNOPARKS
}

This article reviews the activity of innovative technoparks, which have a prominent role in the formation of a modern economy. The best practices used to develop techno parks in ad-vanced countries are generalised based on comparisons. The structure of scientific and technological parks operating in developed countries is explored based on different sources. The activity of international and regional institutions connecting and regulating the functioning of technoparks is analysed, and the structures that promote the development of technoparks is explained. The problems of location selection and property relations are analysed as the main factors in technopark management. A general analysis of management parameters pertaining to all technoparks is conducted, and several recommendations are made.

Keywords: innovative technopark, special economic zone, industrial clusters, scientifictechnological park, university technopark, business-incubator, technopolis.

\section{Introduction}

The economies of the majority of developed countries are based on innovations. Important tasks are assigned to technoparks in these countries to regulate and manage innovative activities, and thus it can be assumed that advanced countries have experience in establishing technoparks. The application of successful outcomes of international practices for the establishment, operation, organisation and management of technoparks to the development of technopark structures in Azerbaijan is considered in this paper.

The main goal in "Azerbaijan 2020: The Vision of the Future" Development Concept [1] is the doubling of gross domestic product through the development of non-oil sectors, and the realisation of this growth is based on an innovative and knowledge-based economy. One of the cornerstones of such development is the establishment of modern innovation structures directed at the development and application of high technologies [2]. The industrial and chemical technologies park in Sumgayit [3], the State Fund of Information Technologies Development under the Ministry of Communication and High Technologies in Baku, the high technologies park in Pirallahi, the agropark for agricultural technologies in Shamkir, the industrial park on waste recycling in Balakhani and the high technologies park in Mingachevir were established to provide competitive products and services with export potential and to develop an innovative economy. Such new institutions will provide financial and administrative support for strengthening the Azerbaijani economy, attracting foreign investment, expanding industrial products manufacturing and organising the activities of other socioeconomic and public institutions.

\section{Technoparks as the element of special economic zones}

Technoparks can be developed as separate institutions or attached to a particular university, scientific research institute or large enterprise, or technoparks can be part of special economic zones (SEZs). An analysis of the regional distribution and structural composition of those zones is important. The twenty-first century is marked by the transition from natural resources to high technologies, including the development of nanotechnologies, biotechnologies and information technologies. The role of high technologies in the development of the new economy and its sustainability and durability is decisive. SEZs facilitate the acceleration of sustainable and balanced development by attracting foreign investment, creating new workplaces, increasing employment and maximising these of existing scientific-technical potential to benefit from the geographical conditions of a country and to assist in regional development $[4,5]$. 


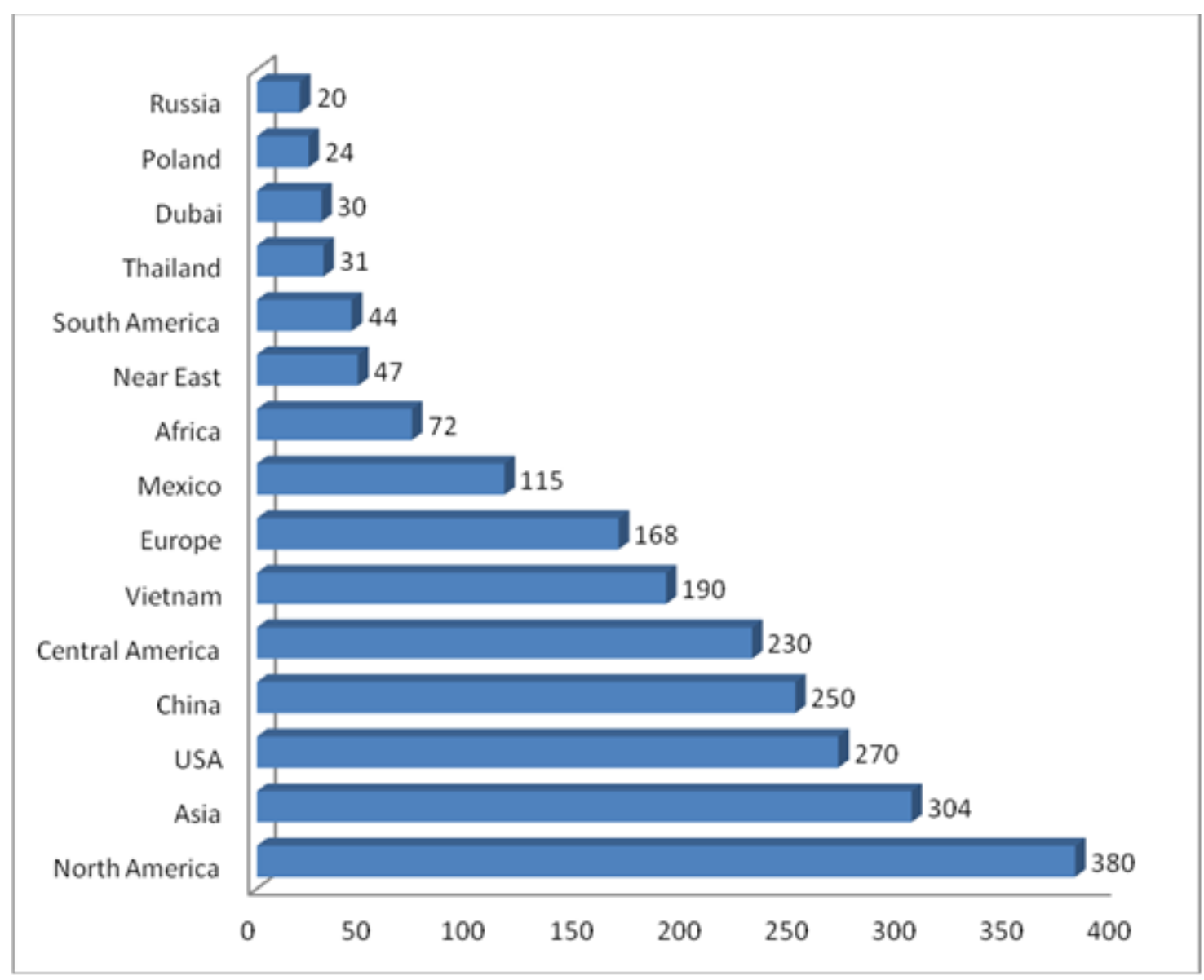

Figure 1. Regions with numerous special economic zones

Some countries use SEZs as economic integration mechanisms; other use them as a means of attracting foreign technologies. Free economic zones, foreign trade zones, industrial entrepreneurship, export processing zones, technoparks, technopolises, tech cities and industrial clusters are types of SEZs. The ICT field has sufficient innovation potential in the economy, so the development of SEZs, including technoparks, is a tool for the economic development of countries with transition economies that seek to establish innovation-intensive small and medium enterprises, reduce the dependence of scientific fields on the state through commercialisation of research, attract foreign companies and potential investors to the ICT market, create jobs and apply high technologies.

Research has shown that more than 3,000 SEZs were established during the last 100 years [4]. Approximately 1,000SEZs are located in developed countries. The majority of SEZs deal with production and trade processes in some form, and almost $10 \%$ of world exports were attributed to SEZs in the past five years. Currently, SEZs are operating in more than 130 countries. More than 500,000companies are functioning, and around 50 million workers are employed in those companies in the almost 1,300 SEZs currently operating around the world. The majority of SEZs are found in a small number of countries or regions. More than $70 \%(2,175)$ of SEZs are concentrated in 15 countries or regions (Figure 1). As the figure shows, SEZs have mainly been established in North America (380 or 12\%), Asia (304 or 10\%), the US (270 or 9\%) and China ( 250 or $8 \%)$.

Technoparks can also be included in clusters with different purposes. The dynamics of cluster formation have evolved in the last 20 years [6,7]. About half of the economy in developed countries is allocated to clusters [8]. (The distribution of clusters in large countries is shown in Figure 2). The establishment of clusters has been considered in Azerbaijan. The establishment of 
an industrial cluster in one of the main regions of the country, Neftchala, and the high technologies park in Mingachevir have commenced following the resolution of the President of the Republic [9].

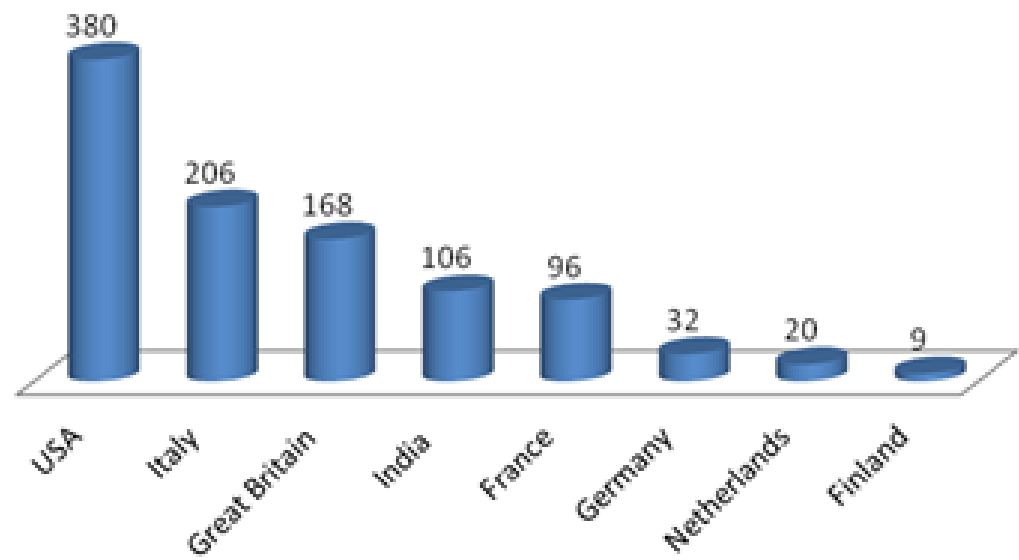

Figure 2. Cluster distribution in developed countries

\section{On the number and structure of active technoparks in the world}

The first technopark was established in 1950, and by 1980, 21 technoparks were functioning globally: 12 in the US, seven in France and Belgium and two in England. Currently, there are nearly 4,000 technoparks in the world [10]. Nearly 300 innovation centres are in the US. In Europe there are over 1,500 large scientific-technological parks, including 40 technoparks in France; Germany has40 scientific parks, 18 technoparks, and hundreds of innovation centres in Germany; the UK has40 technoparks and34 university scientific parks; there are nearly 20 technoparks in Finland; Belgium has one high technologies park and one technopark; there are 165 industrial parks in Hungary; and 44 technoparks in Turkey. Russia has 84 technoparks, and more than 60 university technoparks; there are 12 technoparks in Ukraine; over 40 business incubators and eight innovative centres in Kazakhstan; In China there are nearly 130 high-tech development zones at different levels, 50 technoparks, and 120 high technologies zone; India has 14 technoparks; there are 20 technopolises in the Philippines; 25 technopolises and more than 10 technoparks in Japan; and more than 1,000 technological companies in Korea. The technoparks are mainly concentrated in the US, Europe and Southeast Asia [11].

Almost 100 resident enterprises are functioning in 50\% of technoparks in advanced countries, 100 to 200 enterprises in $16 \%$ of technoparks and over 200 enterprises in 20\% [12]. More than half $(53 \%)$ of the technoparks in the world are engaged in the establishment of new business trends. Over $80 \%$ of technoparks receive government subsidies. Technoparks utilise some criteria such as performance evaluations, such that half of them assess their performance according to the number of created workplaces, $15 \%$ evaluate it with the number of newly established companies, $16 \%$ based on the number of attracted companies, $6 \%$ according to the number of commercialised licenses and patents, and 6\% with information depicted in the mass media concerning the technopark activity $[13,14]$.

Almost three-quarters $(72 \%)$ of technoparks consider job creation as a principal motivator of their activity. More than $60 \%$ of technoparks consider the attraction of foreign investments as a primary goal. 


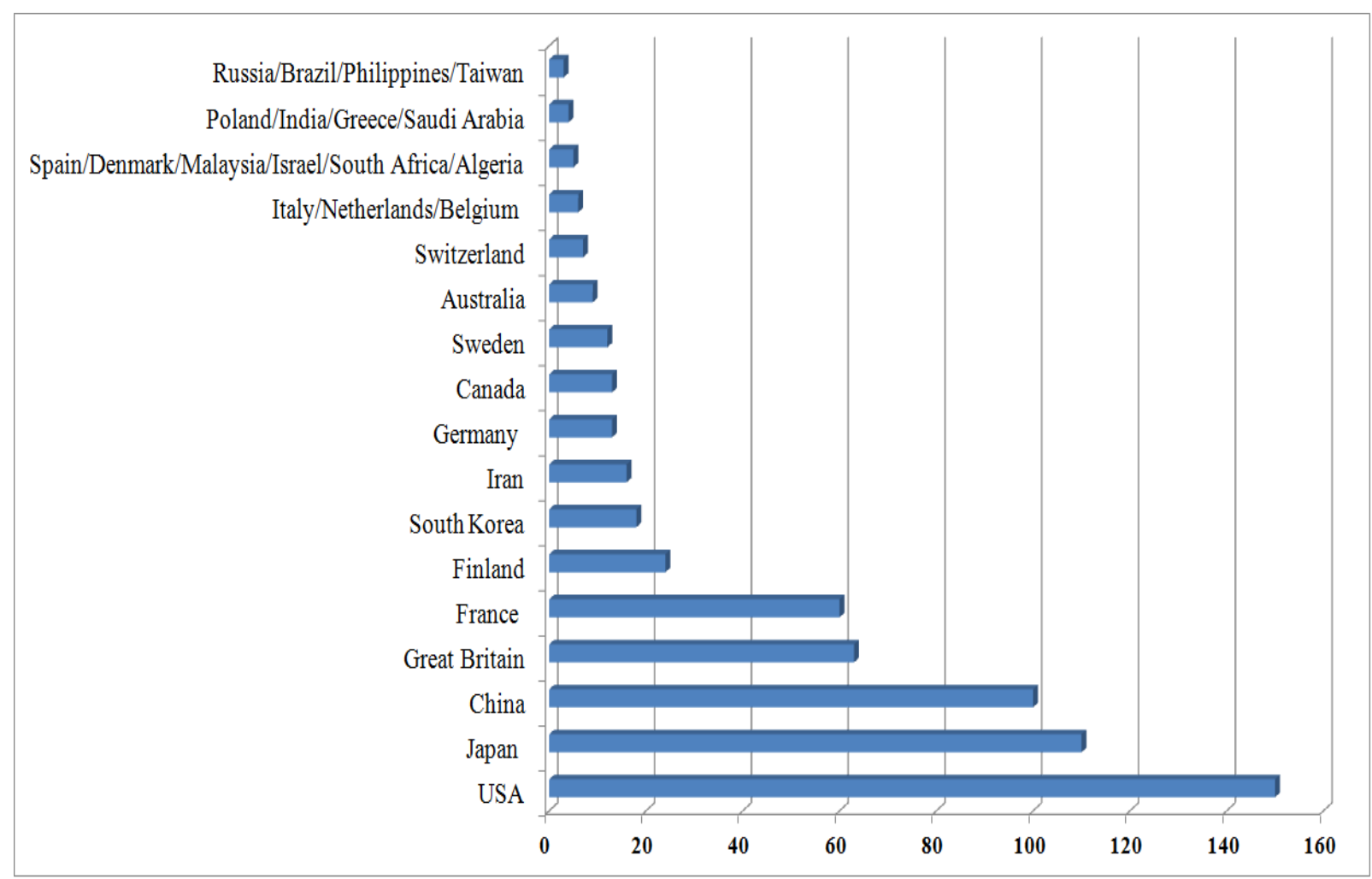

Figure 3. Regions and countries with prevailing number of scientific parks [15]

The number of technoparks exceeds 4,000 according to information on the United Nations Educational, Scientific and Cultural (UNESCO) website [15] and the technological development association of Turkey [10], and nearly 900 scientific parks are currently functioning in the world. Almost $80 \%$ of technoparks are related to the establishment of business-incubator centres [16]. Scientific parks are largely formed in accordance with the level of scientific-technological development (Figure 3): there are 150 scientific parks (or 14\%) in the US, 110 (or 10\%) in Japan, 100 (or 9\%) in China, 63 (or 5.7\%) in the UK, and 60 (or 5.4\%) in France.

As observed, 567 scientific parks exist in 10 countries, which constitutes $63 \%$ of total number of scientific parks, but this information does not match that of the International Scientific Parks Association (ISPA) [17]. ISPA provides information regarding 392 scientific parks in 73 countries, of which 270 are full members, 51 are partial members and 71 are associate members. The distribution of those scientific parks in advanced countries is shown in Figure 4. 


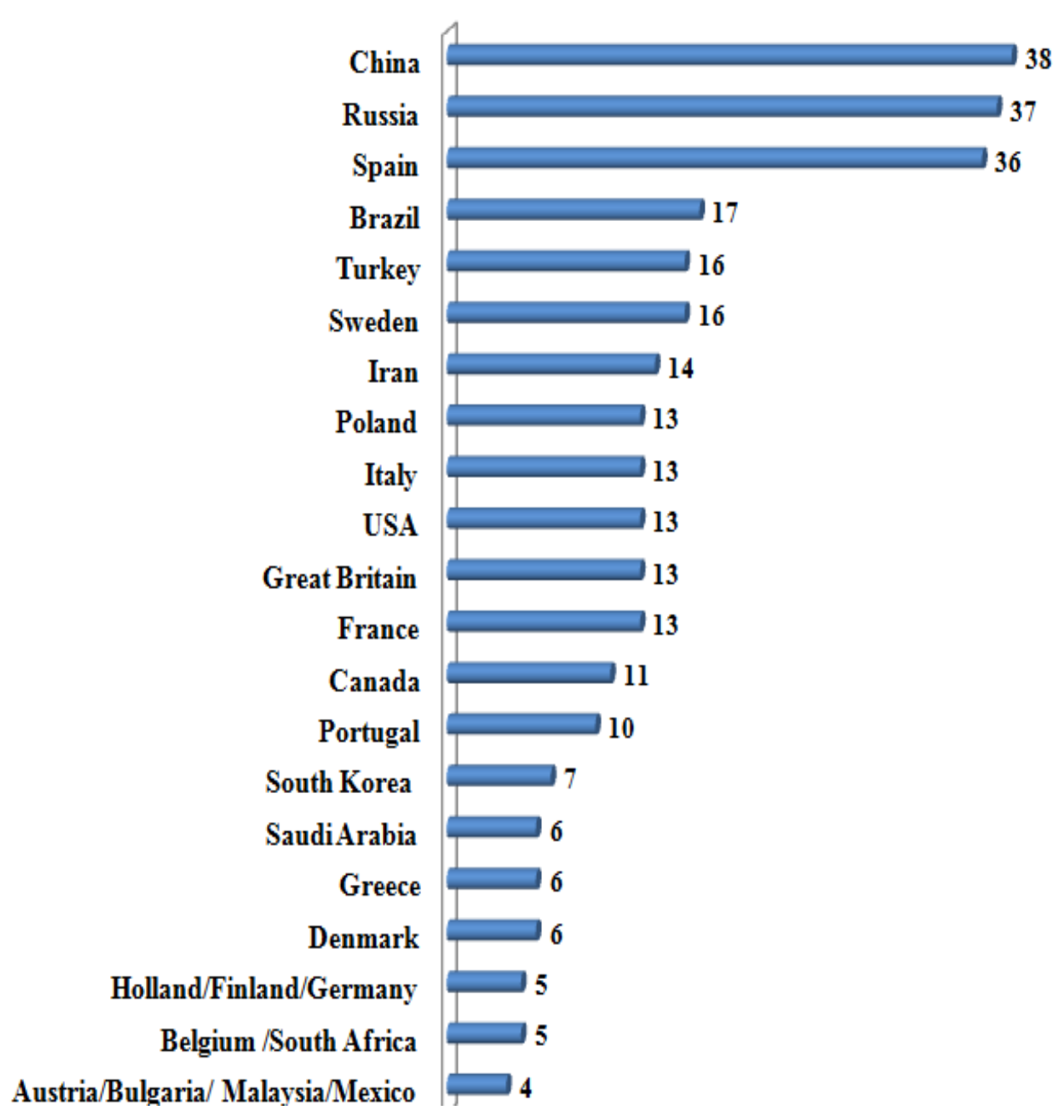

Figure 4. Distribution of scientific parks in advanced countries [17]

\section{International institutions regulating the activity of technoparks}

There are institutions coordinating and regulating the activity of technoparks and other innovation-technological centres globally. ISPA, the most prominent of them, was established in 1984.ISPA assists its members, performs coordination and regulation and offers advice regarding innovation, innovative entrepreneurship, knowledge and new technology transfer.

The ISPA headquarters is in Spain; the number of ISPA members [17] is 396, the number of enterprises is 128,000, the number of member countries is 73 , and the number of departments active in regions is six(Africa, Asia, Europe, Latin America, South America, WGANA). Technoparks can be full members or candidate members of the Association. Japan, China, France, Spain, the Netherlands, Canada, Germany, Italy, Russia, Denmark, Turkey and other advanced countries are full members of ISPA.The number of technoparks in member countries according to regions is shown in Figure 5 [17]. The growth dynamics of member technoparks of ISPA is shown in Figure 6 [17]. As the figure shows, the number of association members has grown from 260 in 2003 to 396 in 2013 in the last 10 years. 


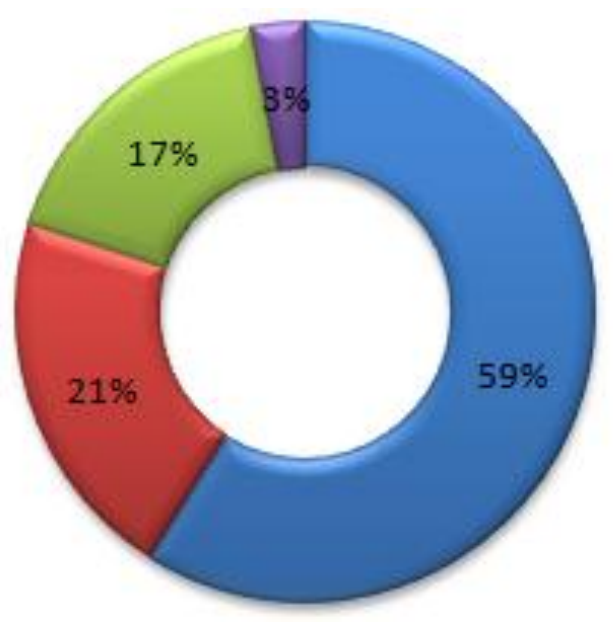

Europa

Asia

$\square$ America

Africa

Figure 5. The distributional structure of technoparks active in member countries of ISPA

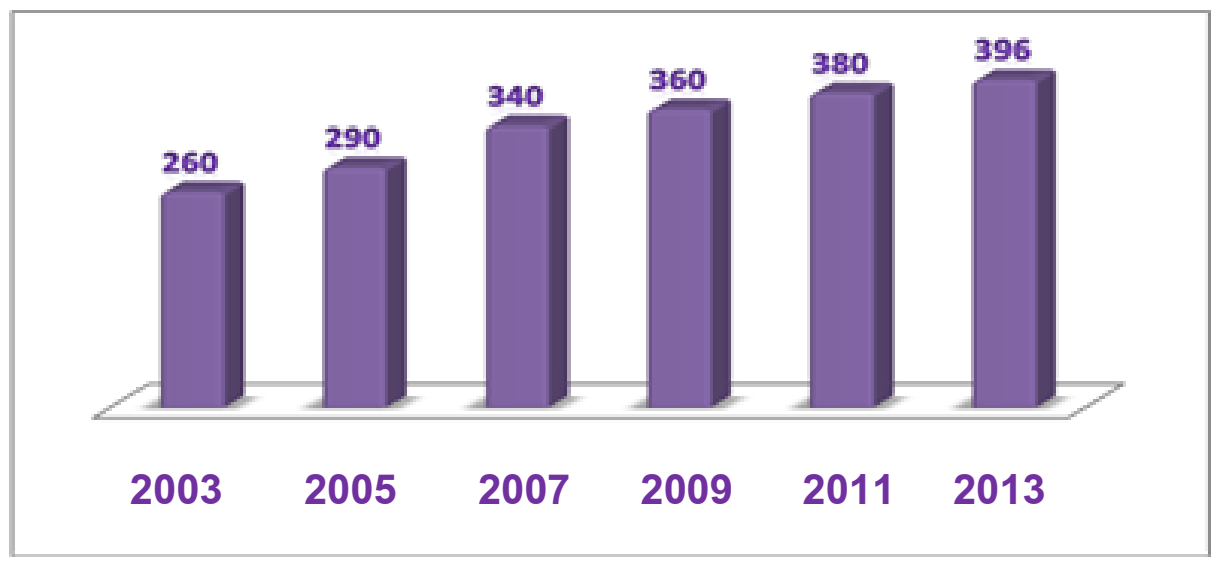

Figure 6. Growth dynamics of ISPA members

Other international organisations are also engaged in the regulation of technoparks $[18,21]$ including the Association of University Research Parks (AURP), the Asian Science Park Association (ASPA), the United Kingdom Science Park Association (UKSPA), the World Technopolis Association (WTA) and the Russian Technoparks Association. Each organisation is engaged in corresponding works with innovation institutions in accordance with its own goals. International organisations such as the World Alliance for Innovation (WAINOVA) and the National Business Incubation Association (NBIA) conduct the analysis and compile statistics on technoparks worldwide [19].Other Internet portals and networks collect information regarding innovation structures:

- www.2wm.co.uk;

- www.innovationnetworks.com;

- www.innonet.org;

- www.ninesigma.com;

- www.innovbusiness.ru;

- www.arip.ru;

- www.extech.ru;

- www.miiris.ru [20].

ISPA is a member of the World Alliance for Innovation (WAINOVA) [21], which is a global network uniting large scientific parks and innovative business incubators. Its members include the 
German Association of Innovation, Technology and Business Incubation Centres; the Argentinean Association of Business Incubators, Science Parks and Technopolis(AIPyP); the Brazilian Association of Technology Parks and Business Incubators (ANPROTEC); the Italian Association of Science and Technology Parks (APSTI); the Association of Science and Technology Parks of Spain (APTE).

\section{Analysis of the functioning and problems of technoparks}

ISPA regularly provides statistical information on current trends in the functioning of technoparks [22]. The statistics include the following elements: 1) the structure of technoparks' activities; 2) incubated companies within scientific and technological parks; 3) the territory selection for locating technoparks; 4) the main elements included in scientific and technological parks; 5) the location of technoparks in cities; 6) the area appointed for the activities of scientific and technological parks; 7) the specialisation of scientific parks; 8) information regarding the property of technoparks [22]. A preliminary analysis has been conducted and the following diagrams have been prepared using the information posted on ISPA's website (Figure 7).

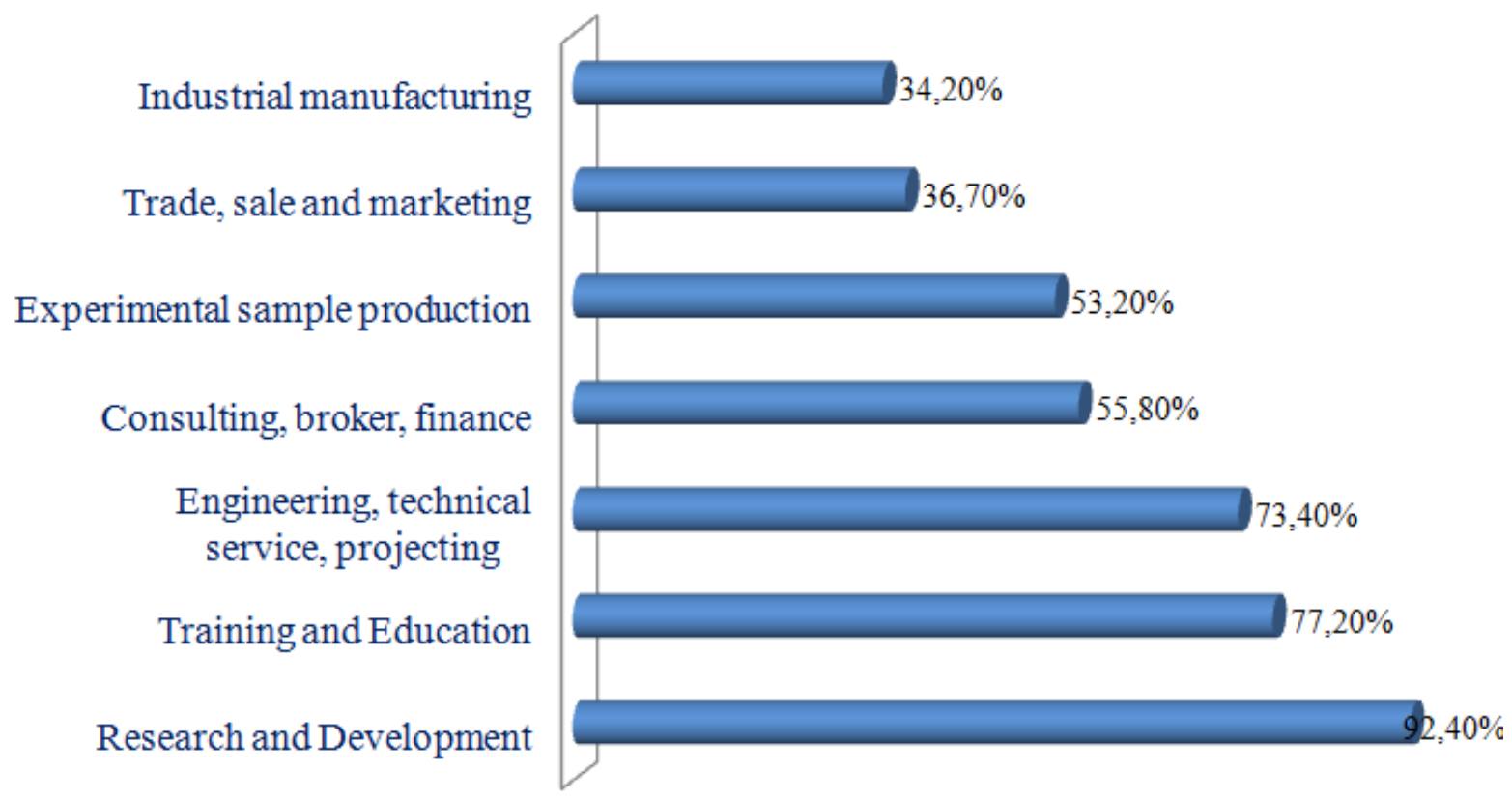

Figure 7. The structure of activity of technoparks functioning

As Figure 7 shows, scientific research and development work prevails in $92.4 \%$ of scientific parks, and $77.2 \%$ of technoparks are engaged in training and education, while $34.2 \%$ engage in trade, sales and marketing (Figure 7).The information on the integral elements included in the structure of scientific and technological parks is shown in Figure 8, which indicates that incubators constitute $91.6 \%$ of the integral parts of technoparks, $80.7 \%$ are scientific research institutes and $42.9 \%$ is composed of universities. 


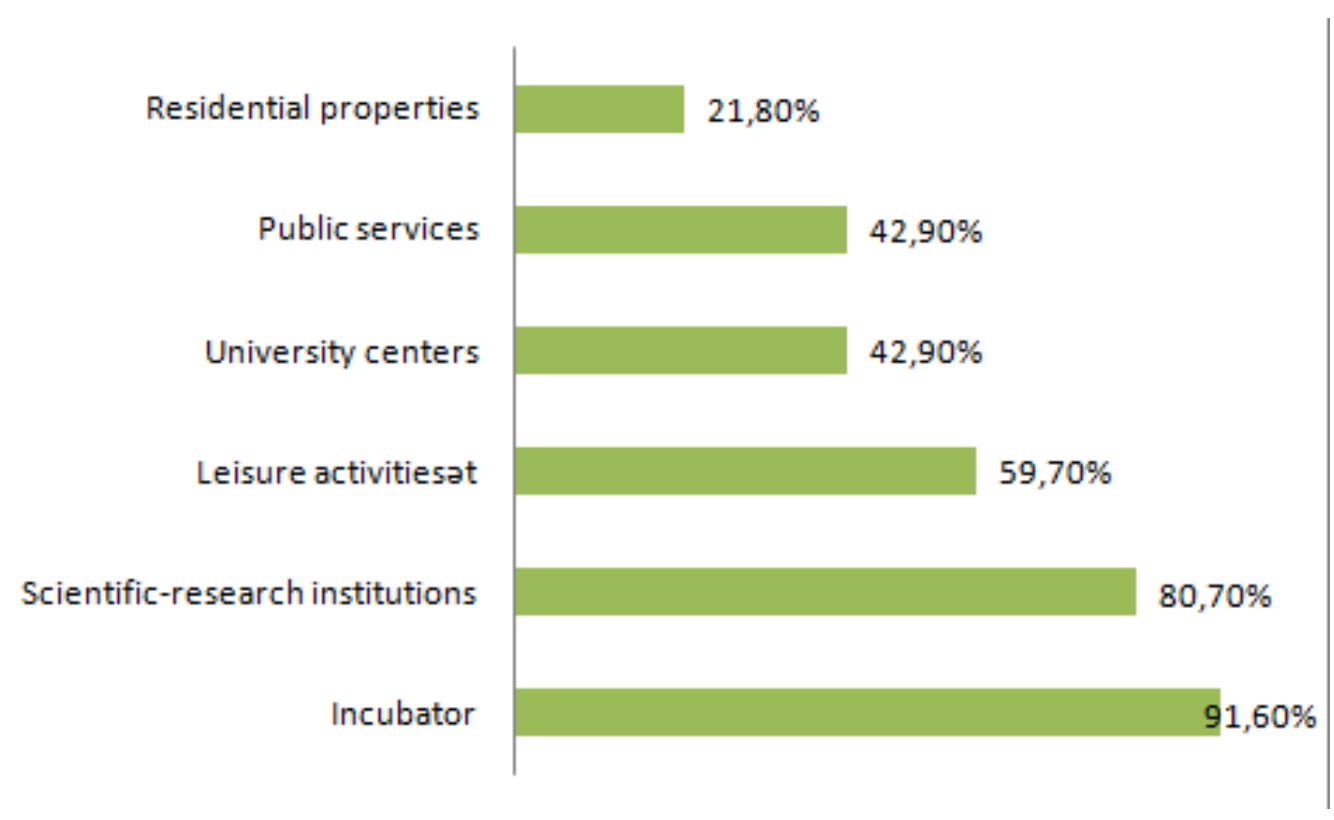

Figure 8. Integral elements of technoparks

One of main issues for the normal activity of technoparks is theirlocation (Figure 9). As the figure shows, $45.4 \%$ of technoparks are located in small cities, $35.5 \%$ are situated in large cities, and $13.4 \%$ in medium-size cities.

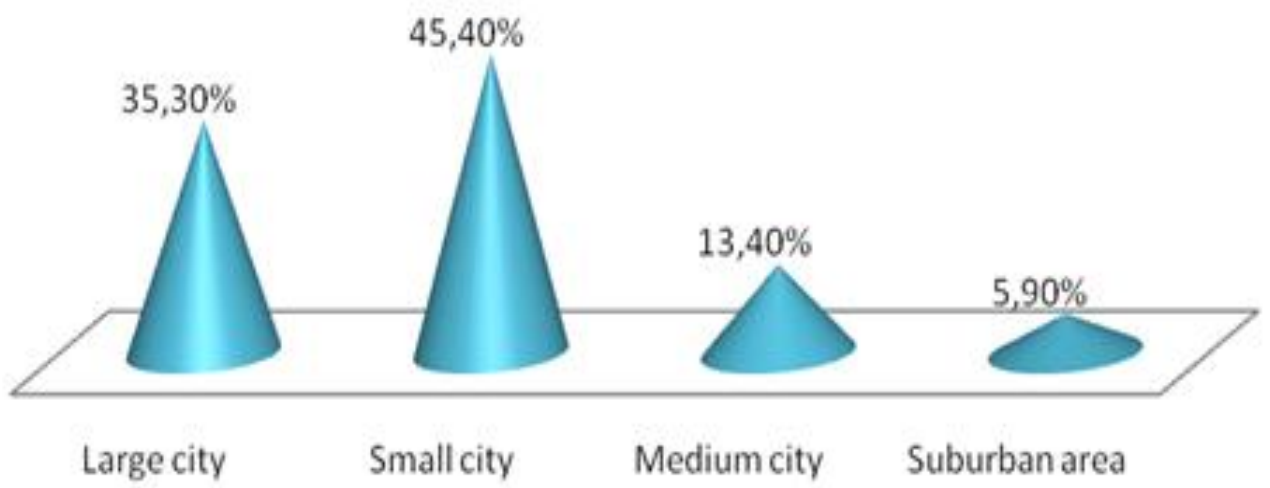

Figure 9. Location structure of technoparks in cities with different scope

One of principal conditions for technoparks' activity is the size of their area and whether that area meets particular requirements. The area allocated for technoparks must be situated in 1) an area close to a city; 2) a region with favourable features for inhabitants; 3 ) a region which is a base of scientific research having educational institutions with skilled professionals engaged in scientific research; 4) an area close to scientific institutions and universities conducting research and able to develop new technologies [22]. According to one study, 70\% of technoparks of ISPA members are established in the central part of a city, 25\% in an area close to city (not further than $25 \mathrm{~km}$ ), $5 \%$ in $25 \mathrm{~km}$ distance from city, $56 \%$ in large cities, and $44 \%$ in small cities [22].

Of Central European technoparks, $92 \%$ are organised in higher education bases, $4 \%$ in field and academic scientific-research centres and $4 \%$ in industrial enterprises centres. Half $(50 \%)$ of technoparks have a small area (up to 20 hectares), $41 \%$ host fewer than 300 workplaces, $21 \%$ host more than 300 workplaces, and $4 \%$ of technoparks include more than 400 workplaces. More than 55\% 
of Russia technoparks are located near technical universities, 37\% near traditional universities, $4 \%$ near scientific-research institutions and $4 \%$ near industrial enterprises [12].

\section{Specialisation of technoparks based on activity areas}

Worldwide, technoparks have established specialisations in particular areas depending on their purpose and the activities they perform. ISPA reports that more than14\% (or 197) of technoparks are represented in ICT and telecommunications field, 11\% (or 156) in biotechnology, 9\% (or 122) in an environmental or ecological field, $8 \%$ (or 115) in healthcare and pharmacy, $7.5 \%$ (or 113) in the energy sector and $7 \%$ (or 101) are in the electronics field [23].Those fields currently have the highest demand for innovative products. Regarding the specialisation of some technoparks, for example, $33 \%$ of Russian technoparks are in information technologies, $25 \%$ are in high-tech chemistry, $16 \%$ are in nanotechnologies, $5 \%$ are biomedical, $2 \%$ relate to the nuclear industry and space, and $19 \%$ are other activities. In China, $65 \%$ are specialised in the field of industrial production, $25 \%$ are in biology or biomedicine, $7 \%$ are in optical electronics and $3 \%$ are in electronics and information technologies. In Turkey, $47 \%$ of technoparks are ICT, $20 \%$ are electronics, $12 \%$ are telecommunications, $7 \%$ are medical and biomedical technology and14\% are other fields.

The specialisation status of world technoparks based on ISPA data is shown in the figure below (Figure 10).

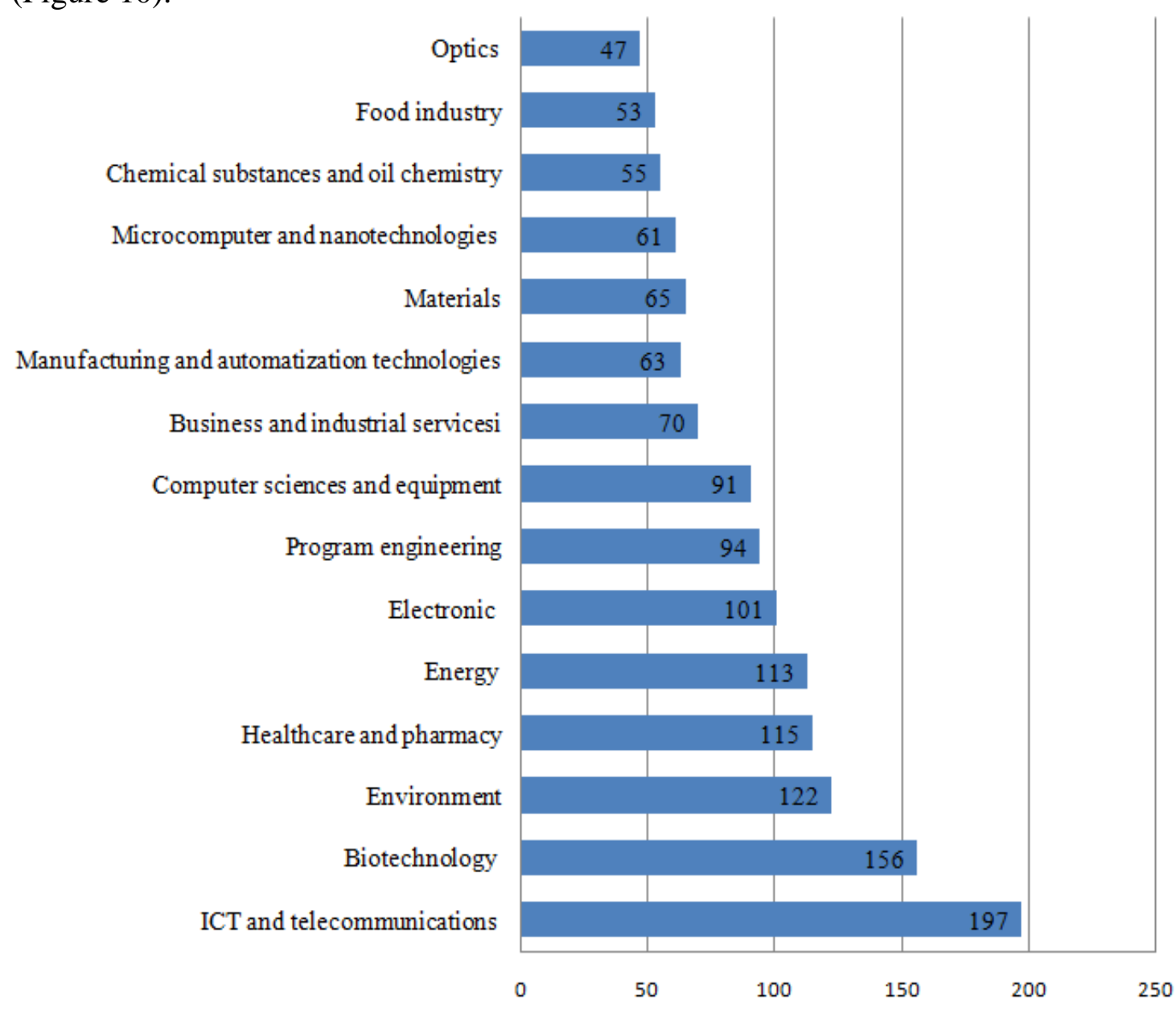

Figure 10. Specialization of technoparks on activity fields

As observed, 1,400 technoparks or 35\% are specialised in 15 areas. The generalisation of the practices of advanced countries suggests that the close location of technoparks to city or suburban universities, the completion of construction in three to four years, the role of state support, 
sufficient investments, effective organisation of science-education-production relations and efficient implementation of the stages of innovative research are factors that make technoparks successful. Unsatisfactory realisation of any of those factors at a particular level becomes a serious obstacle to full achievement of the technopark's goal. Hence, international cooperation, innovation entrepreneurship and the prioritisation of innovative activity must factor into the process of establishing technoparks.

\section{Property relations in technoparks of foreign countries}

The analysis of the property structures of scientific-technological parks showed that $33 \%$ of technoparks worldwide were organised by institutions and government bodies. According to property type, there are state technoparks established through the participation of different government administration bodies, private technoparks based on private property, and mixed technoparks based on private and public property. Of European technoparks, $45 \%$ are mixed, $17 \%$ are private and $38 \%$ are state owned [19]. Overall, $71 \%$ of technoparks globally are state owned. Technoparks established by private investors constitute $21 \%$ of the global total and only $8 \%$ are mixed private-public property.

According to ISPA, $54.6 \%$ of technoparks are state-owned, $29.4 \%$ are mixed and $16 \%$ are private [22]. In the US, $64 \%$ of technoparks are established on state property at different levels, including $25 \%$ on municipal property, $21 \%$ on local administrative agency property, $18 \%$ on federal property, $18 \%$ on university property, $8 \%$ on the property of chambers of commerce and $4 \%$ on the property of banks. In Europe, $45 \%$ of technoparks are mixed, $38 \%$ are state-owned and $17 \%$ are privately owned. In Russia, $9.3 \%$ are private property, $6.7 \%$ are venture property, $13.3 \%$ are state and non-university property, $22.7 \%$ belong to university-affiliated bodies and $48 \%$ perform on the property of university branches.

\section{Conclusion}

The study of the global establishment, organisation and management of technoparks, which is the main element of innovation infrastructure, has a prominent role in the development of the modern economy. This paper showed that the numerical distribution and structure of special economic zones, industrial clusters and scientific and technological parks supports decisionmaking in similar fields. Applying the outcomes of the successful activities of innovative technoparks in developed countries and appropriate technopark models to technoparks in Azerbaijan will help in the development of innovative technoparks.

\section{References}

1. Order of the Prezident of Republic of Azerbaijan on approval of "National Strategy on development of information society in Republic of Azerbaijan for 2014-2020 years", 2 April 2014. Available at: http://www.president.az

2. "Azerbaijan - 2020: the vision for future" Development Concept. Baku, 29 December 2012. Available at: http://www.president.az

3. Resolution of the Prezident of Republic of Azerbaijan dated 5 November 2012 on Establishment of High Technologies Park. Available at: http://www.president.az

4. Aliyev S.T. Application problems of special economic zones, Baku, 2012. 360 p.

5. Tuan F.A. Practice of functioning of special economic zones (theoretical aspect) // Bulletin of Institute of Economics, RAS, 2009, №3, pp. 162-169.

6. Ivanova O.Y. Generalization of foreign practice of clusters and technoparks development as a factor of activization of innovative activity // Science and Economics, №6 (14), pp. 162-169.

7. Lenchuk E. B., Vlaskin G.A. A cluster-based strategy for Russia's innovative development. Studies on Russian Economic Development. November 2010, volume 21, Issue 6, pp. 603-611. 
8. Kwon Y.S. Innovation and Networks in Industrial Clusters: Empirical Results from Three Large Cities, Technopolis, 2014, pp. 263-280.

9. Resolution of the Prezident of Republic of Azerbaijan on Establishment of Mingachevir High Technologies Park. Baku, 26 February 2015. Available at: http:// www.president.az.

10. http://www.tgbd.org.tr/tr/teknopark-tanimi-16.html, http://www.unesco.org

11. Kotelnikov N.V., Nagaeva A.V. Analysis and development perspectives of technopark as an object of innovative infrastructure // News TPU, 2014, №6, pp. 126-130.

12. Kostyunina G.M., Baronov V.I. Technoparks in foreign and Russian practice // News MSUFA - University, 2012, №3, pp.91-99.

13. Tenyakova O.A. Innovative infrastructure: aspects of modern status and development // World of science, culture and ecucation, 2014, № 2(45), pp. 423-425.

14. Rodríguez-Pose A., Hardy D. Are Parks in Emerging Countries Delivering? Technology and Industrial Parks in Emerging Countries. SpringerBriefs in Regional Science 2014, pp. 67-95

15. http://www.unesco.org/new/en/natural-sciences/science-technology/university-industrypartnerships/science-parks-around-the-world

16. Boroughs B.B. Clusters/Science Parks/Knowledge Business Incubators. Innovation Policy. SpringerBriefs in Entrepreneurship and Innovation, 2015, pp 65-84.

17. http://www.iasp.ws

18. Lyashenko Y.A., Pavlovskaya A.V. Foreign practice of technoparks development // International scientific-practical conference on "Innovation Management". RAS. Institute of administration problems named after V.A. Trapeznikov RAS. 14-16 November 2011, pp.261-270.

19. Maltseva A.A., Chevishev V.A. World development trends of technoparls structures: selective analysis // Problem analysis and state-administration projection. 2012, №2, pp.29-42.

20. www.innonet.org, www.wainova.org, http://www.wtanet.org

21. http://www.iasp.ws/statistics

22. http://www.iasp.ws/by-technology-sector

23. Yim D.S., Seong Y.C., Lee W.I., Park S., Hong J.K.. Management and Governance Issues in the Development of Science and Technology Based Innovation Cluster. Published in: Technology Management in the Energy Smart World (PICMET), 2011 Proceedings of PICMET '11. Conference: July 31 2011-Aug. 4 2011. pp.1-8 